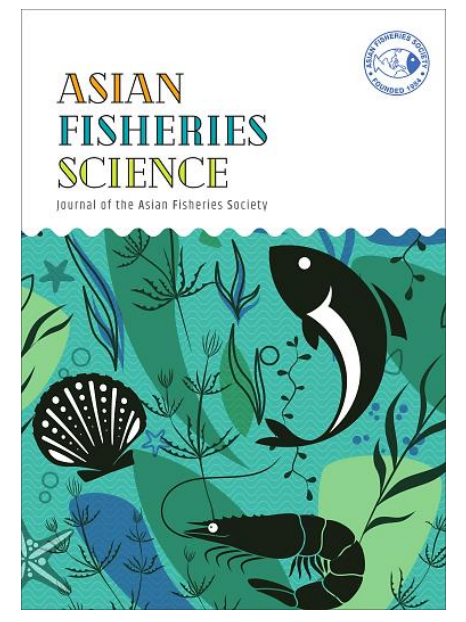

SHORT COMMUNICATION

\title{
Induced Breeding of Rainbow Snakehead (Channa bleheri Vierke, 1991) Under Captive Condition
}

\author{
NIPEN NAYAK* , JYOTIRMOY SONOWAL, RIMLE BORAH, SHYAMA PRASAD BISWAS \\ Department of Life Sciences, Dibrugarh University, Dibrugarh 786004, Assam, India
}

*E-mail: nipennayak2014@gmail.com | Received: 14/07/2020; Accepted: 22/12/2020

(C)Asian Fisheries Society

ISSN: 0116-6514

E-ISSN: 2073-3720

https://doi.org/10.33997/j.afs.2020.33.4.009

\begin{abstract}
Channa bleheri Vierke, 1991 is an endemic snakehead fish confined to certain pockets of Dibrugarh and Tinsukia districts of Brahmaputra basin of Assam and Dikrong River of Arunachal Pradesh, India. Extensive exploitation in aquarium trade through wild catches has resulted in a declining trend in population dynamics of the species, leading to its categorisation in Near Threatened category in the IUCN Red List of Threatened Species (ver. 3.1). The present investigation was conducted to captive breed the species reared under confined condition during June and July, 2019 in Dibrugarh University premises, Assam. A successive increase of hormone dosage (Ovasis) from $0.1 \mathrm{~mL}^{\mathrm{kg}} \mathrm{kg}^{-1}$ body weight was injected intravenously, albeit spawning was experiential with dosage of $0.5,0.6$ and $0.7 \mathrm{~mL}^{-\mathrm{kg}^{-1}}$ body weight. Results indicated that the latency period, fertilisation rate and hatching rate with different hormonal dosages varied from $22-32 \mathrm{~h}, 53-81 \%$ and $65-85 \%$, respectively. The abiotic factors during breeding trials were monitored and documented. The present investigation highlights the possibility of captive breeding of $\mathrm{C}$. bleheri reared under captivity, which will be pivotal in management and conservation of the species.
\end{abstract}

Keywords: Brahmaputra basin, hormone, fertilisation rate

\section{Introduction}

Channa bleheri Vierke, 1991 is one of the few species of Channidae family that doesn't possess a pelvic fin (Britz, 2013). Often regarded as one of the most colourful snakehead species, the species is a major attraction in international ornamental fish trade (Courtenay Jr. and Williams, 2004; Praveenraj et al., 2019). The species has restricted distribution and has been reported only from Dibrugarh and Tinsukia districts of upper Brahmaputra basin of Assam and Dikrong River of Arunachal Pradesh, India (Vishwanath and Geetakumari, 2009). Due to habitat destruction, anthropogenic stress and extensive exploitation from the wild for ornamental fish trade, the population of $C$. bleheri is in a declining trend (Goswami et al., 2006; Lakra et al., 2010). Raghavan et al. (2013) enlisted the species as one of the few freshwater endemic species of India threatened by the aquarium trade. The amalgamation of these threats on the species necessitates immediate interventions to conserve the species in their natural habitats.

A common measure undertaken globally to decrease habitat and productivity pressures on ornamental fishes is captive breeding. It has been recognised as a viable alternative to wild harvest as well as supplementation of existing or restoring threatened fish populations (Rakes et al., 1999; Tlusty, 2002). Captive breeding and reintroduction of different species into the wild have shown positive outcomes in different regions of the world (Philippart, 1995; Sarkar et al., 2006). Despite its debatable implications on fish biodiversity, it has made significant contribution in their management and conservation by reducing pressure on the depleted stocks and sustainable utilisation of aquatic resources (Diana, 2009; De Silva, 2012). Captive breeding of some members of Channa has been achieved with substantial success (Marimuthu et al., 2009; Paray et al., 2013; Hazarika et al., 2014). However, studies regarding C. bleheri are few (Gogoi et al., 2013; Kalita et al., 2018) with no 
detailed records on their rearing and breeding. Keeping this in view, the present investigation was carried out to breed captive reared C. bleheri using synthetic hormone ovasis for effective induced spawning. Inferences drawn from the study may play a significant role in their management and conservation in the near future.

\section{Materials and Methods}

\section{Collection of brooders}

Brooders were collected from different lentic and lotic natural water bodies of Dibrugarh and Tinsukia districts of Assam, India, using traditional bamboo traps called 'Dingora' and 'Sepa' and were brought to the ornamental fish rearing and breeding centre in Dibrugarh University premises, Assam. Length and weight of the brooders were recorded and released in rearing setups for further studies.

\section{Acclimatisation and conditioning of the brooders}

The brooders were acclimatised for 21 days in cemented and open fibre tanks in an environment with artificial hideouts and aquatic plants. The rearing tanks were washed with $5 \% \mathrm{KMnO}_{4}$ solution before introducing the fish in these tanks. The fish were conditioned with live feed such as mosquito larvae, earthworms and ant larvae as well as high protein commercial feed @ 4-5 g. $\mathrm{kg}^{-1}$ body weight daily during the acclimatisation period. Commercial feed with 47 $\%$ protein, $5 \%$ crude fat, $10 \%$ moisture, $17 \%$ ash content, $1 \%$ phosphorous, vitamin A 10,000 IU. $\mathrm{kg}^{-1}$, vitamin D 2,500 $\mathrm{IU} . \mathrm{kg}^{-1}$, vitamin E 2,000 $\mathrm{IU} . \mathrm{kg}^{-1}$ and ascorbic acid $510 \mathrm{mg}^{\mathrm{kg}}{ }^{-1}$ was used to feed the brooders.

\section{Monitoring water parameters}

The water parameters during rearing were monitored weekly using API freshwater master test kit (Indus Marketing, India) following APHA (2004). Different physico-chemical parameters like air temperature, water temperature, precipitation, $\mathrm{pH}$, dissolved oxygen, hardness and alkalinity were also monitored.

\section{Breeding trials}

Six breeding trials; two on $5^{\text {th }}$ June and one each on $6^{\text {th }}$ June, $22^{\text {nd }}$ June, $3^{\text {rd }}$ July and $10^{\text {th }}$ July, 2019, respectively with three setups in each trial was carried out. Days of breeding were selected based on the weather forecast for the next 3 days to meet the optimum environment condition required for breeding as mentioned in Table 1. Healthy brooders were selected and transferred to the breeding tank 2 days prior to breeding and at the same time segregation of male and female was also carried out. The females were identified based on the bulging belly, smooth pectoral fin against rough and rounded genital papillae against elongated in male fish. Gravid fish were randomly selected for breeding trails irrespective of any preferences. Synthetic hormone with the brand name Ovasis (USV Private Limited, Mumbai, India) containing salmon gonadotropin releasing analogue - $20 \mathrm{mcg}$, domperidone IP - $10 \mathrm{mg}$ and propylene glycol added to make the final volume of $10 \mathrm{~mL}$ was used for the trial. A successive increase in hormone (Ovasis) dosage i.e. control, 0.1, 0.2, 0.3, $0.4,0.5,0.6$ and $0.7 \mathrm{~mL} . \mathrm{kg}^{-1}$ body weight diluted with saline water (1:1) was administered both intramuscularly and intravenously. A ratio of 2:1 (male:female) fish was maintained in each setup. A total of 54 gravid fish with 6 fish in each setup were released in an open circular experimental tank measuring $2.25 \times 1.5 \mathrm{~m}$ (radius $\times$ height) with artificial water circulatory system. The breeding tanks were supplied with Eichhornia crassipes and some artificial hideouts. The fish were immediately released in the tank following injection and abnormal movement inside the water if any was observed carefully. The latency period and egg incubation time were calculated by the time taken to lay eggs after injection and hatching of eggs post fertilisation. Fertilisation rate and hatching rate were calculated by estimating the number of fertilised eggs as compared to total eggs while the latter by the number of hatched eggs against total fertilised eggs.

\section{Results and Discussion}

The present study on induced breeding of $C$. bleheri indicated the influence of various factors on successful spawning activity. Among them, the physico-chemical parameters of water during the breeding period are vital for successful fertilisation and hatching rate (Alam et al., 2009). Different physico-chemical parameters such as weather (cloudy or rainy), air temperature $\left(24-30{ }^{\circ} \mathrm{C}\right)$, water temperature $\left(23-28{ }^{\circ} \mathrm{C}\right)$, precipitation $(72-92 \%), \mathrm{pH}$ (7.2-7.6), dissolved oxygen (7.25-7.8 mg. $\left.\mathrm{L}^{-1}\right)$, hardness (43-52 mg. $\mathrm{L}^{-1}$ of $\mathrm{CaCO}_{3}$ ) and alkalinity $\left(42-53 \mathrm{mg} \cdot \mathrm{L}^{-1}\right.$ of $\mathrm{CaCO}_{3}$ ) were monitored and are presented in Table 1.

The weather condition and water parameters of the breeding enclosures were found to be favourable for spawning of $C$. bleheri. Similar findings were also observed in spawning activity of Channa punctata (Bloch, 1793) (Marimuthu et al., 2009) and Channa striata (Bloch, 1793)(Hossain et al., 2008).

During the present investigation, induced breeding with differential doses of ovasis hormone showed variation in spawning behaviour in $C$. bleheri. Spawning was not observed in fish administered with low hormone dosages $\left(0.1,0.2,0.3,0.4 \mathrm{~mL} . \mathrm{kg}^{-1}\right.$ body weight) but showed successful spawning with $0.5,0.6$ and $0.7 \mathrm{~mL} . \mathrm{kg}^{-1}$ body weight dosages (Table 2).

However, in contrast to the present findings, Marimuthu and Haniffa (2011) and Yulintine et al. (2017) observed spawning with hormonal dosage of 


\begin{tabular}{lllllllll}
\hline $\begin{array}{l}\text { Date of } \\
\text { experiment }\end{array}$ & Weather & $\begin{array}{l}\text { Air temp. } \\
\left({ }^{\circ} \mathrm{C}\right)\end{array}$ & $\begin{array}{l}\text { Water temp. } \\
\left({ }^{\circ} \mathrm{C}\right)\end{array}$ & $\begin{array}{l}\text { Precipitation } \\
(\%)\end{array}$ & $\mathrm{pH}$ & $\begin{array}{l}\text { Dissolved } \\
\mathrm{O}_{2}\left(\mathrm{mg} . \mathrm{L}^{-1}\right)\end{array}$ & $\begin{array}{l}\text { Hardness } \\
(\mathrm{ppm})\end{array}$ & $\begin{array}{c}\text { Alkalinity } \\
(\mathrm{ppm})\end{array}$ \\
\hline $05 / 06 / 2019$ & Cloudy & 30 & 28 & 72 & 7.2 & 7.34 & 47 & 48 \\
\hline $06 / 06 / 2019$ & Cloudy & 29 & 26 & 74 & 7.4 & 7.45 & 43 & 42 \\
\hline $22 / 06 / 2019$ & $\begin{array}{l}\text { Cloudy } \\
\text { L3/07/2019 }\end{array}$ & 27 & 24 & 91 & 7.2 & 7.25 & 45 & 53 \\
\hline $\begin{array}{l}\text { Light rain } \\
\text { (35mm) }\end{array}$ & 26 & 23 & 92 & 7.4 & 7.68 & 48 & 49 \\
\hline $\begin{array}{l}\text { Light rain } \\
\text { (36mm) }\end{array}$ & 24 & 23 & 80 & 7.6 & 7.8 & 52 & 48 \\
\hline
\end{tabular}

Table 2. Summary of Channa bleheri breeding trials using different doses of Ovasis hormone.

\begin{tabular}{|c|c|c|c|c|c|c|c|c|}
\hline $\begin{array}{l}\text { Date of } \\
\text { experiment }\end{array}$ & $\begin{array}{l}\text { Weight of } \\
\text { female } \\
(\mathrm{gm})\end{array}$ & $\begin{array}{l}\text { Dosage of } \\
\text { hormone } \\
\text { (mL. } \mathrm{kg}^{-1} \\
\text { body } \\
\text { weight) }\end{array}$ & $\begin{array}{l}\text { Weight of } \\
\text { male (gm) }\end{array}$ & $\begin{array}{l}\text { Dosage of } \\
\text { hormone } \\
\text { (mL. } \mathrm{kg}^{-1} \\
\text { body } \\
\text { weight) }\end{array}$ & $\begin{array}{l}\text { Latency } \\
\text { period } \\
\text { (h) }\end{array}$ & $\begin{array}{l}\text { Fertilisation } \\
\text { rate } \\
(\%)\end{array}$ & $\begin{array}{l}\text { Hatching } \\
\text { rate } \\
(\%)\end{array}$ & $\begin{array}{l}\text { Egg } \\
\text { incubation } \\
\text { time } \\
\text { (h) }\end{array}$ \\
\hline 05/06/2019 & $\begin{array}{l}14.49 \pm \\
2.36\end{array}$ & 0.1 & $\begin{array}{l}20.23 \pm \\
1.12\end{array}$ & 0.1 & - & - & - & - \\
\hline 05/06/2019 & $\begin{array}{l}10.80 \pm \\
0.96\end{array}$ & 0.2 & $\begin{array}{l}14.45 \pm \\
2.12\end{array}$ & 0.2 & - & - & - & - \\
\hline 06/06/2019 & $\begin{array}{l}18.15 \pm \\
4.33\end{array}$ & 0.3 & $\begin{array}{l}15.6 \pm \\
0.66\end{array}$ & 0.3 & - & - & - & - \\
\hline 06/06/2019 & $\begin{array}{l}22.96 \pm \\
3.49\end{array}$ & 0.4 & $\begin{array}{l}19.12 \pm \\
1.89\end{array}$ & 0.4 & - & - & - & - \\
\hline 05/06/2019 & $\begin{array}{l}20.04 \pm \\
0.72\end{array}$ & 0.5 & $\begin{array}{l}18.91 \pm \\
0.35\end{array}$ & 0.5 & $26-30$ & 53 & 71 & $46-48$ \\
\hline 06/06/2019 & $\begin{array}{l}18.16 \pm \\
3.84\end{array}$ & 0.5 & $\begin{array}{l}15.06 \pm \\
6.88\end{array}$ & 0.5 & 28-32 & 50 & 65 & $48-50$ \\
\hline 05/06/2019 & $\begin{array}{l}24.00 \pm \\
3.85\end{array}$ & 0.6 & $\begin{array}{l}21.29 \pm \\
4.47\end{array}$ & 0.6 & $22-26$ & 80 & 85 & 44-46 \\
\hline 22/06/2019 & $\begin{array}{l}24.63 \pm \\
3.85\end{array}$ & 0.6 & $\begin{array}{l}21.29 \pm \\
4.47\end{array}$ & 0.6 & $23-27$ & 81 & 82 & $45-48$ \\
\hline 03/07/2019 & $\begin{array}{l}20.23 \pm \\
0.66\end{array}$ & 0.7 & $\begin{array}{l}14.49 \pm \\
4.99\end{array}$ & 0.7 & $28-32$ & 54 & 81 & 48-52 \\
\hline 10/07/2019 & $\begin{array}{l}22.23 \pm \\
1.83\end{array}$ & 0.7 & $\begin{array}{l}20.52 \pm \\
0.84\end{array}$ & 0.7 & $26-30$ & 56 & 78 & $46-50$ \\
\hline
\end{tabular}

$0.4 \mathrm{~mL} . \mathrm{kg}^{-1}$ and $0.3 \mathrm{~mL} . \mathrm{kg}^{-1}$ body weight in C. punctata and C. striata, respectively. In this regard, Billard et al. (1984) and Peter et al. (1987) had earlier reported that differences in dose requirement in different fish species are due to varied level of dopamine activity. Furthermore, Hoga et al. (2018) reported that an administration of higher hormone dose might result in liver damage leading to mortality of the brooders. In our study, mortality of some brooders was observed when administered with a dose of $0.7 \mathrm{~mL} . \mathrm{kg}^{-1}$. Some eggs were found attached to the substratum during post-spawning; while others remained free-floating as in case of other Channa species (Marimuthu et al., 2007; Hossain et al., 2008; Marimuthu and Haniffa, 2011). Britz (2013) reported that C. bleheri tend to guard the buoyant floating eggs at the water surface post-spawning. However, no such observations were made during our study. The latency period in $C$. 
bleheri(22-27 h) was found to be similar with that of $C$. punctata (23.5-28.5 h) administered with same hormonal dosage of $0.6 \mathrm{~mL} . \mathrm{kg}^{-1}$ body weight (Hossain et al., 2008). Marimuthu et al. (2007) reported 23 to 27 $\mathrm{h}$ of latency period at $29 \pm 1.5^{\circ} \mathrm{C}$ when induced with ovatide hormone in C. striata. These observed variations of latency period may be attributed to the differential inhibitory effect of dopamine on gonadotropin-releasing hormone (Dufour et al., 2010). The fertilisation and hatching rate was found highest with $0.6 \mathrm{~mL} . \mathrm{kg}^{-1}$ body weight ( $80-81 \%$ and $82-85 \%$ ) as compared to $0.5 \mathrm{~mL} \cdot \mathrm{kg}^{-1}(50-53 \%)$ and $0.7 \mathrm{~mL} \cdot \mathrm{kg}^{-1}(65-$ $71 \%$ ) body weight, respectively. In the present study, optimal hormonal dose $\left(0.6 \mathrm{~mL} . \mathrm{kg}^{-1}\right)$ slightly deviated from the findings of Yulintine et al. (2017) in C. striata $\left(0.5 \mathrm{~mL} . \mathrm{kg}^{-1}\right)$ and Marimuthu et al. (2009) in C. punctata $\left(0.4 \mathrm{~mL} . \mathrm{kg}^{-1}\right)$. Moderate doses of hormone were found to be more effective with better fertilisation and hatching rate as compared to higher dose in C. striata and C. punctata (Marimuthu et al., 2009; Yulintine et al., 2017). In the present study too, less fertilisation rate was recorded with higher hormone dosage (Table 2). A significant difference $(P<0.05)$ of hormone dosage against latency period, fertilisation rate, hatching rate and egg incubation time was observed (F-test, ANOVA). Sarkar et al. (2006) also found similar differences in captive breeding of Chitala chitala (Hamilton, 1822).

The egg incubation time (34-42 h) and yolk dissolution time post-hatching (34-42 h) was longer in C. bleheri as compared to C. striata (Yulintine et al., 2017), Channa marulius (Hamilton, 1822) (Amornsakun et al., 2011); Koi carp (Haniffa et al., 2003) and C. chitala (Sarkar et al., 2006). These results suggest significant variation in incubation time and yolk dissolution in different groups of fish. In this regard, Brooks et al. (1997) reported the influence of water temperature on incubation and spawning success. Similar observations were also made by Amornsakun et al. (2011) on the influence abiotic parameters on survival rate of the hatchings.

\section{Conclusion}

The findings of the present study noticeably demonstrate the effectiveness of hormone ovasis on spawning as well as seed production of $C$. bleheri reared under captive conditions. Results indicated that administration of $0.6 \mathrm{~mL} . \mathrm{kg}^{-1}$ body weight of ovasis hormone showed encouraging outcomes and thus the dose can be treated as optimum dose for breeding this species. However, further investigation for the development and standardisation of breeding protocol of local fish species like $C$. bleheri is necessary to encourage the aqua-culturists for mass propagation and inclusion of endemic and rare species in aquaculture programme.

\section{Acknowledgements}

The authors are grateful to Department of
Biotechnology (DBT), Government of India, for providing financial assistance under DBT Twinning Project (North East Region) and also to the authority of Dibrugarh University for providing necessary facilities during the study period.

\section{References}

Alam, M., Alam, M.S., Alam, M.A., Islam, M.A., Miah, M.I. 2009. Dose optimization with PG hormone for induced breeding of Mastacembelus pancalus. Journal of Eco-friendly Agriculture 2:799804.

Amornsakun, T., Sriwatana,W., Promkaew, P. 2011. Some aspects in early life stage of snake head fish, Channa striatus larvae. Songklanakarin Journal of Science and Technology 33:671-677.

APHA. 2004. American water works Association and Water Pollution control Federation. Standard methods for the examination of water and waste water. American Public Health Association 20:1134-1135.

Billiard, R., Bieniarz, K., Peter, R.E., Sokolowska, M., Weil, C. 1984. Effect of LHRH and LHRH-a on plasma $\mathrm{GtH}$ levels and maturation/ovulation in common carp, Cyprinus carpio kept under various environmental conditions. Aquaculture 41:245-254. https://doi.org/10.1016/0044-8486(84)90287-4

Britz, R. 2013. Channa andrao, a new species of dwarf snakehead from West Bengal, India (Teleostei: Channidae). Zootaxa 3731:287-294.

Brooks, S., Tyler, C.R., Sumpter, J.P. 1997. Egg quality in fish: What makes a good egg? Reviews in Fish Biology and Fisheries 7:387-416. https://doi.org/10.1023/A:1018400130692

Courtenay Jr., W.R., Williams, J.D. 2004. Snakeheads (Pisces, Channidae) - A biological synopsis and risk assessment. U.S. Geological Survey Circular 1251. 143 pp.

De Silva, S.S. 2012. Aquaculture: a newly emergent food production sector-and perspectives of its impacts on biodiversity and conservation. Biodiversity and Conservation 21:3187-3220. https://doi.org/10.1007/s10531-012-0360-9

Diana, J.S. 2009. Aquaculture production and biodiversity conservation. Bioscience 59:27-38. https://doi.org/10.1525/bio.2009 $\underline{.59 .1 .7}$

Dufour, S., Sebert, M.E., Weltzien, F.A., Rousseau, K., Pasqualini, C. 2010. Neuroendocrine control by dopamine of teleost reproduction. Journal of Fish Biology 76:129-160. https://doi.org/10.1111/j.10958649.2009.02499.x

Gogoi, R., Behera, S., Borah, B.C., Bhuyan, S. 2013. Sexual dimorphism and gonadal development of a rare murrel species Channa bleheri (Bleher) in Assam. The Bioscan 8:1265-1269.

Goswami, M.M., Borthakur, A., Pathak, J. 2006. Comparative biometry, habitat structure and distribution of four endemic snakehead (Teleostei: Channidae) species of Assam, India. Journal of the Inland Fisheries Society of India 38:1-8.

Haniffa, M.A., Nagarajan, M., Marimuthu, K., Arockia Raj, A.J. 2003. Embryonic and larval development of spotted murrel, Channa punctatus (Bloch). Indian Journal of Fisheries 50:355-362.

Hazarika, L.P., Bakalial, B., Baruah, D., Biswas, S.P. 2014. Successful breeding of an endemic murrel, Channa aurantimaculata Musikasinthorn, 2000 with a habitat manipulation practice. Annals of Biological Research 5:10-15.

Hoga, C.A., Almeida, F.L. Reyes, F.G.R. 2018. A review on the use of hormones in fish farming: Analytical methods to determine their residues. CyTA - Journal of Food 16:679-691. https://doi.org/10.1080 $\underline{\text { /19476337.2018.1475423 }}$ 
Hossain, M.K., Latifa, G.A., Rahman, M.M. 2008. Observations on induced breeding of snakehead murrel, Channa striatus (Bloch, 1793). International Journal of Sustainable Crop Production 3:65-68.

Kalita, M., Choudhury, H., Saikia, A., Sarma, D. 2018. Length-weight relationships of four endemic snakeheads [Channa andrao Britz, 2013, Channa aurantimaculata Musikasinthorn, 2000, Channa bleheri Vierke, 1991, and Channa stewartii (Playfair, 1876)] from the Brahmaputra drainage, northeast India. Journal of Applied Ichthyology 34:1367-1368. https://doi.org/10.1111/jai.13804

Lakra, W.S., Sarkar, U.K., Gopalakrishnan, A., Kathirvelpandian, A. 2010. Threatened freshwater fishes of India. National Bureau of Fish Genetic Resources (Indian Council of Agricultural Research), Lucknow. 20 pp.

Marimuthu, K., Haniffa, M.A. 2011. Induced spawning of native threatened spotted snakehead fish Channa punctatus with ovaprim. Indian Journal of Science and Technology 4:228-229.

Marimuthu, K., Haniffa, M.A., Rahman, M.A. 2009. Spawning performance of native threatened spotted snakehead fish, Channa punctatus (Actinopterygii: Channidae: Perciformes), induced with ovatide. Acta Ichthyologica Et Piscatoria 39:1-5. https://doi.org/10.3750/AIP2009.39.1.01

Marimuthu, K., Kumar, D., Haniffa, M.A. 2007. Induced spawning of striped snakehead, Channa striatus, using Ovatide. Journal of Applied Aquaculture 19:95-103. https://doi.org/10.1300 IJ028v19n04_06

Paray, B.A., Haniffa, M.A., Manikandaraja, D., Milton, M.J. 2013. Breeding behavior and parental care of the induced bred striped murrel Channa striatus under captive conditions. Turkish Journal of Fisheries and Aquatic Sciences 13:707-711. https://doi.org/10.4194 /12303-2712-v13_4_16

Peter, R.E., Sokolowska, R., Nahorniak, C.S., Rivier, J.E., Vale, W.W. 1987. Comparison of [D-Arg ${ }^{6}, \operatorname{Trp}^{7}$, Leu $^{8}$, Pro $\left.^{9} N E t\right]$-luteinizing hormone-releasing hormone (sGnRH-A), and [D-Ala ${ }^{6}$, Pro $\left.{ }^{9} \mathrm{NEt}\right]-$ luteinizing hormone-releasing hormone (LHRH-A), in combination with pimozide, in stimulating gonadotropin release and ovulation in the goldfish, Carassius auratus. Canadian Journal of Zoology 65:987991. https://doi.org/10.1139/z87-156

Philippart, J.C. 1995. Is captive breeding an effective solution for the preservation of endemic species? Biological Conservation 72:281295. https://doi.org/10.1016/0006-3207(94)00090-D

Praveenraj, J., Uma, A., Moulitharan, N., Singh, S.G. 2019. A new species of dwarf Channa (Teleostei: Channidae) from Meghalaya, northeast India. Copeia 107:61-70. https://doi.org/10.1643/Cl-18-079

Raghavan, R., Dahanukar, N., Tlusty, M.F., Rhyne, A.L., Kumar, K.K. Molur, S., Rosser, A.M. 2013. Uncovering an obscure trade: threatened freshwater fishes and the aquarium pet markets. Biological Conservation164:158-169. https://doi.org/10.1016 li.biocon.2013.04.019

Rakes, P.L., Shute, J.R., Shute, P.W. 1999. Reproductive behavior captive breeding and restoration ecology of endangered fishes. Environmental Biology of Fishes 55:31-42. https://doi.org /10.1023/A:1007531927209

Sarkar, U.K., Deepak, P.K., Negi, R.S., Singh, S., Kapoor, D. 2006. Captive breeding of endangered fish Chitala chitala (HamiltonBuchanan) for species conservation and sustainable utilization. Biodiversity and Conservation15:3579-3589.https://doi.org/10.1007 1978-1-4020-5734-2_15

Tlusty, M. 2002. The benefits and risks of aquacultural production for the aquarium trade. Aquaculture 205:203-219. https://doi.org /10.1016/S0044-8486(01)00683-4

Vishwanath, W., Geetakumari, K. 2009. Diagnosis and interrelationships of fishes of the genus Channa Scopoli (Teleostei: Channidae) of northeastern India. Journal of Threatened Taxa 1:97-105. https://doi.org/10.11609/JoTT.01788.97-105

Yulintine, Bugar, H., Wulandari, L., Harteman, E. 2017.Snakehead fish (Channa striata):Semi-induced breeding and larval growth. Indian Journal of Science and Technology 10:2-8. 